\title{
Community Adaptation to the Hebei-Spirit Oil Spill
}

\author{
So-Min Cheong ${ }^{1}$
}

\begin{abstract}
The focus of the research is the significance of dependence for communities to survive and adapt in times of environmental disasters. It shifts the emphasis on self-reliant communities for survival and examines the types and effects of dependence and external linkages by analyzing the range of community responses that include initial responses, early social impact, compensation, and conflicts after the Hebei-Spirit oil spill in December 2007 in Korea. The findings reveal that dependence is necessary, and the effects of dependence can be both positive and negative depending on the relations between external entities and affected communities as well as the community capacity to absorb resources and information.
\end{abstract}

Key Words: community adaptation; community dependence; resource; Hebei-Spirit; knowledge; oil spill

\section{INTRODUCTION}

How do communities adapt to new environmental disasters? A paradigm within the literature on disaster management and climate change adaptation is the promotion of self-reliance and self-sufficiency, for communities to initiate action to prevent and prepare for disasters and to determine for themselves how to manage and adapt to disasters and climate change (Allen 2006). This places a high priority on local knowledge, and the capacity of local communities to respond effectively (Dekens 2007). Such community-based management is premised on the basis that disasters are experienced first by locals and first responders are generally locals (Cutter et al. 2012). This aligns with the policy perspective that a key solution to community resilience is to raise community adaptive capacity, encourage local communities to fend for themselves, and apply decentralized governance.

My research on community adaptation to environmental disasters challenges this conventional wisdom and the belief in such a local-centered, bottom-up approach. Rather it suggests that dependence and external linkages are also important and can positively influence community adaptation to extreme events and the more gradual processes of environmental change. The understanding of dependence, in addition to self-reliance promoted in community-based management, is central to changing the way community adaptation is envisioned. I examine the types and effects of dependence and external linkages by analyzing the range of community responses that include initial responses, early social impact, compensation, and conflicts after the HebeiSpirit oil spill in December 2007 in Korea. The analysis of responses focuses on the role and effects of external resources and outside knowledge in surviving the environmental crisis and its aftermath as well as the community's capacity to absorb resources and information, the findings reveal that dependence is necessary, and the effects of dependence can be both positive and negative depending on the relations between external entities and affected communities.

\section{BACKGROUND}

Though the advocacy of community-initiated disaster preparedness and adaptation is important to increasing adaptive capacity and sharing local knowledge, local-centered views equally may create insularity that inhibits adaptation to new phenomena, including abrupt or high-impact environmental change (Cheong 2005, 2010b). For example, social capital, now considered an integral part of community survival in times of disasters (Dynes 2006), may not function well without external linkages. A growing literature points to the paradoxical weaknesses of strong ties/bonds within communities (Portes 1998, Elliott et al. 2010, Hawkins and Maurer 2010). For example, a close-knit group's self-belief and collective reinforcement of past experience make it difficult for a community to prepare for heat waves that exceed their expectations (Wolf et al. 2010). People also tend to come back and rebuild in flood-prone zones partly because they are attached to their location. This 'sense of place' is oftentimes engineered because of the existence of social capital (Chamlee-Wright and Storr 2009), and hinders or prevents relocation from places of high risk (Eisenman et al. 2007). Such bonding social capital can foster path dependence to the extent that community know-how and networks become selfreferential (Portes and Landolt 1996, Dale and Newman 2010). In ordinary times, bonding social capital may work well and enhance solidarity. However, in times of crisis and change, it may result in a closed society that lacks innovation and the diversity of resources and knowledge necessary for adapting to change. Insulated local networks can set high barriers against external ideas, information, and resources, and may not foster innovation.

Environmental disasters often exceed the local capacity to cope, and invite external engagement in response to disasters 
and extreme events (Brondizio et al. 2009, Cheong 2011a). Indicative of this was the inflow of external aid and expertise, and the emergence of new groups to cope with the largest oil spills in Korea and the U.S. for both short-term coping and longer-term adaptation. Complex impacts of environmental disasters such as oil spills and extreme climatic events require scientific expertise that communities oftentimes do not possess, and call for the involvement of various (non) government agencies and the private sector to engage with communities (van Aalst et al. 2008). In addition, vulnerabilities and opportunities derive from processes beyond the local level, and addressing issues to reduce vulnerabilities also goes beyond the local scale (Westerhoff and Smit 2009). Thus, the value of dependence on external entities, in addition to self-reliance/sufficiency, needs to be properly recognized and conceptualized in the field of community-based management.

Adaptation in response to large oil spills that have caused severe environmental damage has demonstrated the importance of external links such as to government officials, lawyers, nongovernmental organizations, and volunteers to access assistance on compensation and restoration issues. Though communities tend to self-organize immediately after the disaster before the external assistance arrives, subsequent issues of compensation and restoration, critical after large oil spills, are longer-term and require sustained external resources and information. In the cases of the Erika (France), Prestige (Spain), and Hebei-Spirit (Korea) oil spills, for example, governments have extended their role to include not only coordination of assistance but also financial support to the victims, including the provision of emergency livelihood funds, special loans, advance payments, and/or a supplementary fund when the compensation was to occur mainly between the insurance companies and the affected groups and individuals (Cheong 2011b).

In spite of the significance of external involvement and community dependence, their effects are seldom examined. I analyze the effects by examining the largest oil spill in the Republic of Korea. The Hebei-Spirit tanker spilt about 12,547 metric tons of light crude oil on December 7, 2007, contaminated $150 \mathrm{~km}$ of coastline, and affected fishing, aquaculture, tourism communities, numerous small islands, a national marine park, and migratory bird habitats. Field work consisted of approximately one to two months each year from 2007 to 2010 using qualitative methods such as participant observation, semi-structured interviews with community leaders, government officials, damage assessors, tour operators, and fishermen as well as archival research of policy documents, newspapers, and technical reports.

\section{TYPES OF DEPENDENCE}

In community adaptation to the Hebei-Spirit oil spill, there were two major types of dependences: resources and knowledge. Resource dependence was divided into human/ physical and financial resources. Knowledge dependence included knowledge of dispersant use and financial compensation access.

\section{Resources}

\section{Human Resources}

The government declared a state of disaster in 11 regions: Boryoung, Seosan, Taean, Seocheon, Hongseong, Dangjin, Muan, Shinan, Yeongqwang, Gunsan, and Buan and dispatched cleanup workers immediately. Cleanup workers consisted of the Korea Coast Guard (KCG), Korea Marine Pollution Response Corporation (KMPRC), military, police, private contractors, and over one million volunteers (Table 1). The workers cleaned oil off the sand and rocks, and deployed booms, fishing vessels, and helicopters to spray dispersants.

International experts from the U.S. Coast Guard, the National Oceanic and Atmospheric Administration (NOAA), the Japanese Coast Guard, the Japanese Disaster Relief Team, and the European Union Oil Spill Emergency team arrived in Korea to help with the oil spill assessment. The Marine Environmental Agency Preparedness and Response Regional Activity Center from the Pacific Northwest Region participated as well. Furthermore, a six person team from the Environment Canada Shoreline Cleanup and Assessment Technique (SCAT) group trained community members on SCAT procedures for a couple of weeks.

In addition to resources for cleanup, experts were available to assist with ecological impact studies. The staff from the International Tanker Owners Association (ITOPF) and Korean technical experts travelled with the cleanup crew and community members to initiate damage assessment. Nationally, universities and research centers such as the Korea Ocean Research and Development Institute (KORDI) and the Korea Maritime Institute (KMI) also participated in assessment and research activities. Regional universities from the affected areas were especially keen on conducting social and ecological research in collaboration with the national research centers.

\section{Financial Resources}

Affected communities could draw from three types of financial resources (Table 2). First, the national government emergency fund in the amount of KRW 117.2 billion was made available in December 2007 and January 2008 to the provincial government for distribution to individuals in affected communities (MLTM 2010a). The government also offered a public works program, reduced or exempted national and local taxes, and deferred public insurance premiums (IOPC Funds 2011). Second, the government provided recovery projects including construction, image boosting, and fisheries revitalization projects (Cheong in press). Finally, financial assistance for damage that resulted from cleanup and 
Table 1. Human Resources: manpower and expertise after the Hebei-Spirit oil spill in South Korea.

\begin{tabular}{|c|c|c|}
\hline Clean-up & Compensation & Ecological impact \\
\hline $\begin{array}{l}\text { International } \\
\text { - United Nations Environment Programme (UNEP) } \\
\text { - U.S. Coast Guard } \\
\text { - European Union } \\
\text { - National Oceanic and Atmospheric Administration } \\
\text { (NOAA) } \\
\text { - Northwest Pacific Action Plan } \\
\text { - Japanese Coast Guard }\end{array}$ & $\begin{array}{l}\text { - The International Oil Pollution Compensation } \\
\text { Funds } \\
\text { - The International Tanker Owners Pollution } \\
\text { Federation Limited } \\
\text { - Skuld P\&I }\end{array}$ & $\begin{array}{l}\cdot \text { UNEP } \\
\cdot \text { NOAA }\end{array}$ \\
\hline $\begin{array}{l}\text { National } \\
\text { - Korean Coast Guard } \\
\text { - Korea Marine Pollution Response Corporation } \\
\text { - Ministry of Maritime Affairs and Fisheries (South } \\
\text { Korea) (MOMAF) } \\
\text { - volunteers } \\
\text { - army } \\
\text { - contractors }\end{array}$ & $\begin{array}{l}\text { - MOMAF } \\
\text { - National Fisheries Cooperative }\end{array}$ & $\begin{array}{l}\text { - Korea Ocean Research and Development } \\
\text { Institute } \\
\text { - Chungnam University } \\
\text { - National Fisheries Research and } \\
\text { Development Institute } \\
\text { - Nongovernmental organizations }\end{array}$ \\
\hline $\begin{array}{l}\text { Local } \\
\text { • residents } \\
\text { • local governments }\end{array}$ & $\begin{array}{l}\text { - Fishing village Cooperative } \\
\text { - local tourism associations } \\
\text { - compensation committees }\end{array}$ & - fishermen \\
\hline
\end{tabular}

livelihood loss came from Skuld Protection \& Indemnity (P \& I) Club, and the shipowner's insurance company. The International Oil Spill Pollution Compensation Fund (IOPC Fund) stepped in when the amount of damage exceeded the limit afforded by the P\&I Club. The Special Law established by the Korean government after the spill provides loans and advance payments for claims not processed or paid within six months of submission. In addition, the Law provides supplementary funding to pay for any amount assessed in excess of the amount available for compensation (MLTM 2010a).

\section{Knowledge}

\section{Knowledge of dispersant use}

The new resources have generated new knowledge. With respect to cleanup, people have employed and learned different methods of removing oil. The most controversial cleanup method is the use of dispersants. Some fishers believe that dispersants contaminate fisheries habitats. Some experts, on the other hand, consider the effect of dispersants similar to that of a soap and a necessary measure to break down oil before it reaches shore. The Korea Coast Guard also emphasizes that they used the international standard stipulated in the National Contingency Plan (Cheong 2010a).

\section{Knowledge of compensation process}

Confusion about claims procedures involving foreign organizations such as the ITOPF and the IOPC, the novelty of the spill of this magnitude, and the direct encounter of international agents with locals has characterized the compensation process. To transfer knowledge of compensation, new institutions were established. Internationally, the Hebei Spirit Center opened in Seoul in 2008 by the Skuld P \& I Club and the IOPC to facilitate claims. Nationally, two relevant ministries established the Hebei-Spirit Support Centers, and they offered consulting services and public hearings to explain the compensation procedure. The establishment of the Special Law in 2008 on compensation increased responsibilities for the government as the Support Centers implemented the requirements of the law such as advance payments and loans. The central government also played the role of a mediator between affected communities and the IOPC. For instance, the government explained to the IOPC the subsistence culture of rural communities engaged in clamming and small-scale tourist accommodations that do not generate receipts. At the local level, provincial and county governments created temporary compensation departments to facilitate the exchange of information, distribute emergency funds, loans, and advance payments, and assist with community inquiries. Communities also established their own compensation committees in the areas of fishing and tourism. Some hired their own damage assessors, lawyers, and consultants to conduct independent compensation claims.

\section{EFFECTS OF DEPENDENCE}

\section{Resources}

The effects of external involvement were both positive and negative. Overall communities benefited by getting new sources of money and people. The most beneficial effect of 
Table 2. Financial resources from outside the local economy for disaster recovery and local compensation after the Hebei-Spirit oil spill in South Korea.

\begin{tabular}{lll}
\hline \hline Emergency Fund & Recovery Projects & Compensation \\
\hline $1^{\text {st }}$ round: $\mathrm{KRW}^{\dagger} 30$ billion (US\$27 million) & Construction & Civil Liability Convention \\
& & The International Oil Pollution \\
& & Compensation Funds \\
$2^{\text {nd }}$ round: KRW117.2 billion (US\$104 million) & Image boosting projects & Loans, advance payments \\
Donations & Ecosystem rehabilitation & Supplementary funding \\
\hline
\end{tabular}

South Korean won

dependence was in the area of cleanup. The oil-covered beaches were cleaned in approximately seven days (Figure 1) with the assistance from a number of specialists, volunteers, and residents (Table 1). The downside of the speedy cleanup was the potential and real effects on human and ecosystem health. While cleaning especially in the first week, workers, volunteers, and residents in contact with oil had skin lesions, headaches, eye irritation, neurovestibular and respiratory problems, as well as back pain from the manual labor of removing oil from the rocks, water, and sand (Sim et al. 2010, Cheong et al. 2011b). The long-term ecosystem effects of cleaning oil with high pressure and vacuum cleaning, dispersants, and manual removal remain unknown.

Fig. 1. Hebei-Spirit oil spill cleanup over one week at Mallipo, South Korea.
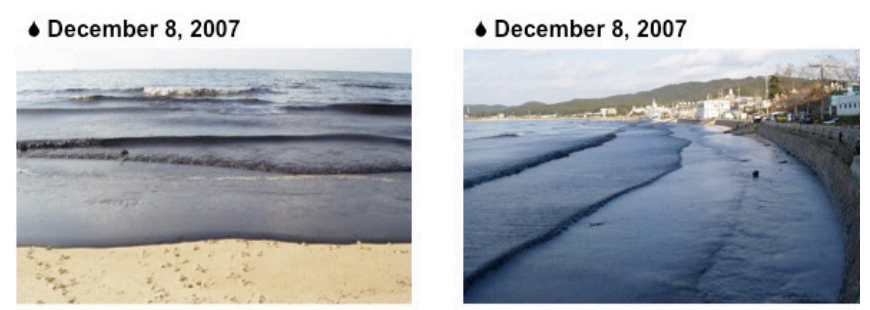

- December 10, 2007
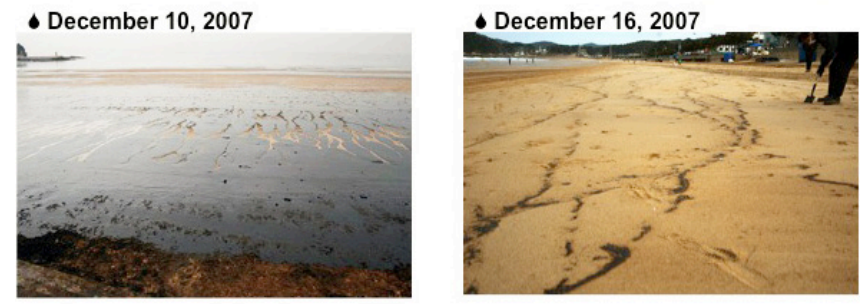

Another benefit derives from the social and psychological support provided by volunteers. Communities considered it as a sign of care from the public when they felt abandoned by the government, Samsung, and the shipping company. Mental clinics and health services offered social and psychological resources for communities. This was especially useful since $64.2 \%$ of the 71 men and women surveyed eight weeks after the Hebei-Spirit oil spill experienced psychosocial distress (Song et al. 2009). In addition, by 2010 four suicides were attributed to the post-spill distress over livelihoods and compensation.

Financial assistance helped communities survive in times of fisheries and beach closures but also created conflicts over the distribution of emergency funds. Locals complained that the distribution of the money was slow and unfair. It took longer than expected for the provincial government to decide the criteria for distribution. Communities were also divided over the amount of money received saying that community leaders did not distribute the funds fairly (Cheong 2011b). The sudden influx of money is often attributed to community conflicts after oil spills (Rodin et al. 1992). However, this is also reflective of the latent conflict within communities and lack of internal cohesion that could surface in the event of an oil spill.

\section{Knowledge}

Dependence on external knowledge has generated more controversies than dependence on resources due to the knowledge gaps between scientific experts and local fishermen and foreign compensation damage assessors and local claimants. Conflicts occur not necessarily because of differences in knowledge. Rather, misperceptions and mistrust of the other are pervasive and deter adequate knowledge transfer. The two most controversial areas of conflict were dispersant use and compensation.

The main concern with dispersant use is its effects on fisheries and fish habitats. Local discourse on dispersant use is typically based on the belief that the dispersants mixed with oil can sink to the bottom of the sea or stay in the water column, and contaminate the fisheries habitats. Affected residents comment that it would have been better to leave the oil as it was so that it could gradually dissipate. Similar local discourse can be seen in the case of the BP Deepwater Horizon oil spill. For example, some residents of Grand Isle say that:

\footnotetext{
"There's no doubt about it. ... they [shrimp catch] 're way down...I think the chemicals in the dispersant had something to do with it.... They should have just let this stuff come to the surface and dealt with it.... All that dispersant was trying to hide what was there or just how much was there" (Zullo 2011).
} 
As such, the scientific knowledge concerning the effects of dispersant use has not been discussed well. Though the government made some efforts to convey the knowledge on the use of dispersants in public meetings in the first few weeks after the spill, the public was not very receptive. It was too technical, and people had other immediate concerns with their livelihoods and compensation. Inadequate time for information transfer and consensus immediately after the spill created confusion and resentment among fishers, tourism businesses, government officials, scientists, media, nongovernment organizations, and the general public. Furthermore, knowledge transfer is especially problematic when local networks are locked and insular. They perpetuate a local belief system validated by an inner circle of well-known or vocal community leaders that spread to the rest of the community. The same logic can be applied to the expert community as experts are locked in their own framework and show a tendency to ignore local knowledge. Similar communication problems can be found in the case of compensation procedures.

As compensation heavily influences the daily lives of locals, there was a greater effort to disseminate information on compensation procedures and documentation requirements for damage proofs by governments, lawyers, and government supported consultants. Director Kim of Taean government compensation department says,

"It took a lot of time to make them [residents] understand, particularly concerning the fact that the central government does not finance compensation. It is the IOPC. Because this is declared a disaster area, people expect the government to pay. However, the spill is based on a different law that is not related to natural disaster. This was very difficult to convey particularly when some spread this misunderstanding. The expectation was that the government compensate all."

A major barrier was the distrust of external entities by the local people. Locals were suspicious of the P\&I Club whose goal they felt was to maximize profit. They believed the IOPC and the ITOPF were working for the P\&I, and sometimes even thought the government sided with the IOPC. Chon in the Fisheries Compensation Department of Taean County says:

\section{"Lawyers do not listen to us. They are not informed well about the claims procedure. Taean county is the most problematic because a lot [of compensation claims are] rejected. Taean hired civil lawyers who are distrustful of government, and did not consult and listen to us."}

This suspicion perpetuated the local's distrust of external authorities but at the same time prompted locals to seek information. Some hired their own damage assessors to respond to what they have perceived as nonlocal and biased assessments.

The nonlocal experts also limited themselves to their own knowledge base. Lee, a Fisheries Compensation Department staff member, says:
"They [IOPC] equate the fisheries closure period with the damage compensation period. They don't care about fisheries catch decline afterwards. Scientific data are required but fishermen cannot generate, and other research centers cannot either. Seohaean fisheries center has past scientific data but the researchers do not volunteer information. The Ph.D.s/research centers don't do anything without money."

A culture of dependence on the government, distrust and suspicion of the insurance company and the IOPC, the unfamiliar interactions between the foreign agents and locals, and the complicated and slow compensation procedures have contributed to conflicts over compensation and generated inadequate knowledge transfer.

\section{CONCLUSION}

For communities to adapt to environmental change, provision of external resources and knowledge is necessary. This shifts the emphasis from self-reliance for community survival and encourages the notion of dependence as a necessary component of adaptation. As such, the effects of dependence are important to assess and understand. In the case of the Hebei-Spirit oil spill the effects were both positive and negative largely due to the nature of the relations between external entities and affected communities and to the capacity of locals to absorb external resources and information. The more unknown and undeveloped the relations are, the more difficult it will be to transfer resources and knowledge without conflicts and controversies. Both can occur if expert and local communities are not aware of each other's knowledge and culture but are locked in their own mode of thinking.

Belief in the validity and trustworthiness of expert knowledge and government-disseminated information hinges upon appropriate knowledge transfer, which occurs over time. It is important to sustain and develop external linkages to familiarize the community with the external entities. This will also help distinguish the sources of assistance efficiently when disaster strikes. Further investigation is necessary to identify the types and strategies to sustain and develop useful external linkages, and how these linkages can be embedded in existing governance to save time and money.

Finally, developing boundary organizations is another way to enhance and facilitate dependence. The Korean government in the case of the Hebei-Spirit oil spill played this role. The central government mediated between the IOPC and the affected communities, and local governments mediated 
between the central government and the communities to placate the affected individuals and provide support. Locating all the relevant organizations such as the central government support center, provincial government oil spill task force, Taean compensation divisions, and community-based compensation committees in the same building in Taean was also beneficial in promoting resource and knowledge transfer.

Responses to this article can be read online at:

http://www.ecologyandsociety.org/vol17/iss3/art26/

responses/

\section{Acknowledgments:}

This research is supported by the Korea Foundation Field Research Fellowship and the Academy of Korea Studies Grant (\#AKS-2008-R33).

\section{LITERATURE CITED}

Allen, K. M. 2006. Community based disaster preparedness and climate adaptation: local capacity building in the Philippines. Disasters 30(1):81-101. http://dx.doi.org/10.1111/ j.1467-9523.2006.00308.x

Brondizio, E. S., E. Ostrom, and O. Young. 2009. Connectivity and the governance of multilevel social-ecological systems: the role of social capital. Annual review of environment and resources 34:253-278. http://dx.doi.org/10.1146/annurev.env iron.020708.100707

Chamlee-Wright, E. and V. H. Storr. 2009. There's no place like New Orleans': sense of place and community recovery in the ninth ward after Hurricane Katrina. Journal of Urban Affairs 31(5):615-634. http://dx.doi.org/10.1111/j.1467-9906 $.2009 .00479 . \mathrm{x}$

Cheong, H. K., M. Ha, J. S. Lee, H. Kwon, E. Ha, Y. Hong, Y. Choi, W. Jeong, J. Hur, S. M. Lee, E. Kim, and H. Im. 2011. Hebei Spirit oil spill exposure and subjective symptoms in residents participating in clean-up activities. Environmental Health Toxicology 26 e2011007.

Cheong, S. 2005. Korean fishing communities in transition: limitations of community-based resource management. Environment and Planning A 37(7):1277-1290. http://dx.doi. org/10.1068/a37139

Cheong, S. 2010a. Initial Responses to the MT Hebei Spirit Oil Spill. Marine Technology Society Journal 44:69-74. http: //dx.doi.org/10.4031/MTSJ.44.1.2

Cheong, S. 2010b. A social assessment of the Hebei-Spirit oil spill. GeoJournal:1-11.

Cheong, S. 2011a. Guest editorial on coastal adaptation. Climatic Change 106(1):1-4. http://dx.doi.org/10.1007/s1058 4-010-9999-y
Cheong, S. 2011b. The Role of government in disaster management: The case of the Hebei-Spirit oil spill compensation. Environment and Planning C 29:1073-1086. http://dx.doi.org/10.1068/c10170

Cheong, S. In press. Fishing and Tourism Impacts in the aftermath of the Hebei-Spirit Oil Spill. Journal of Coastal Research.

Cutter, S., B. Boruff, and W. L. Shirley. 2003. Social Vulnerability to Environmental Hazards. Social Science Quarterly 84(2):242-261. http://dx.doi.org/10.1111/1540-623 $\underline{7.8402002}$

Dale, A. and L. Newman. 2010. Social capital: a necessary and sufficient condition for sustainable community development? Community Development Journal 45(1):5-21. http://dx.doi.org/10.1093/cdj/bsn028

Dekens, J. 2007. Local knowledge for disaster preparedness: a literature review. International Centre for Integrated Mountain Development (ICIMOD): 85. Kathmandu, Nepal.

Dynes, R. 2006. Social capital: Dealing with community emergencies. Homeland Security Affairs 2:1-26.

Eisenman, D. P., K. M. Cordasco, S. Asch, J. F. Golden, D. Glik. 2007. Disaster planning and communication with vulnerable communities: lessons from Hurricane Katrina. American Journal of Public Health 97: S109-S115. http://dx. doi.org/10.2105/AJPH.2005.084335

Elliott, J. R., T. Haney, and P. Sams-Abiodun 2010. Limits to social capital: Comparing network assistance in two New Orleans neighborhoods devastated by hurricane Katrina. Sociological Quarterly 51(4):624-648. http://dx.doi.org/10.11 11/j.1533-8525.2010.01186.x

Hawkins, R. L. and K. Maurer 2010. Bonding, bridging and linking: how social capital operated in New Orleans following Hurricane Katrina. British Journal of Social Work 40 (6):1777-1793. http://dx.doi.org/10.1093/bjsw/bcp087

International Oil Pollution Compensation Funds (IOPC Funds). 2011. Incidents involving the IOPC funds: 1992 fund: Hebei Spirit, note by the Director, International Oil Pollution Compensation Funds, http://www.iopcfund-docs.org/ds/pdf/ IOPC-MAR11-3-7 e.pdf

Ministry of Land, Transport, and Maritime Affairs (MLTM). 2010. Hebei Spirit Oil Spill, Part 1: Compensation. Ministry of Land, Transport, and Maritime Affairs, Republic of Korea

Portes, A. 1998. Social capital: its origins and applications in modern sociology. Annual Review of Sociology24: 1-24. http ://dx.doi.org/10.1146/annurev.soc.24.1.1

Portes, A. and P. Landolt 1996. The downside of social capital. The American Prospect 26(94):18-21.

Rodin, M., M. Downs, J. Petterson, and J. Russell. 1992. Community impacts resulting from the Exxon Valdez oil spill. 
Organization Environment 6(3):219-234 http://dx.doi.org/10. $\underline{1177 / 108602669200600304}$

Sim, M. S., I. J. Jo, and H. G. Song. 2010. Acute health problems related to the operation mounted to clean the Hebei Spirit oil spill in Taean, Korea. Marine Pollution Bulletin 60:51-57. http://dx.doi.org/10.1016/j.marpolbul.2009.09.003

Song, M., Y. Hong, H. Cheong, M. Ha, H. Kwon, E. Ha, E., Y. Choi, W. Jeong, J. Hur, S. Lee, and E. Kim. 2009. Psychological health in residents participating in clean-up works of Hebei Spirit oil spill. Journal of Preventive Medical Public Health 42:82-88. http://dx.doi.org/10.3961/jpmph.200 9.42.2.82

van Aalst, M. K., T. Cannon, and I. Burton. 2008. Community level adaptation to climate change: the potential role of participatory community risk assessment. Global Environmental Change 18(1):165-179. http://dx.doi.org/10.1016/j.gloenvcha .2007 .06 .002

Westerhoff, L. and B. Smit. 2009. The rains are disappointing us: dynamic vulnerability and adaptation to multiple stressors in the Afram Plains, Ghana. Mitigation and Adaptation Strategies for Global Change 14(4):317-337. http://dx.doi.or $\mathrm{g} / 10.1007 / \mathrm{s} 11027-008-9166-1$

Wolf, J., W. Adger, I. Lorenzoni, V. Abrahamson, and R. Raine. 2010. Social capital, individual responses to heat waves and climate change adaptation: An empirical study of two UK cities. Global Environmental Change 20(1):44-52. http://dx.d oi.org/10.1016/j.gloenvcha.2009.09.004

Zullo, R. 2011. Fishermen bemoan poor catches. Houma News Oct. 8 2011. [online] URL: http://www.houmatoday.com/arti cle/20111008/ARTICLES/111009535?p=1\&tc=pg 